\title{
Nexus of Political Connections with Green Financial Development and Fiscal Performance
}

\author{
Luwen Zhang \\ College of Business, East China University of Science and Technology, Shanghai, 200237, China
}

\begin{abstract}
Green finance is an important guarantee to promote the development and structural transformation of green industries in China and is also the power source to implement the concept of green development during the "13th Five-Year Plan". The development of green finance is inseparable from the support of financial and taxation policies. Based on this background, there is a certain connection between green finance and corporate values. When companies strengthen their political relations, there will be certain positive and negative effects on the company's future development. Green development should be the goal, and the financial and tax performance of companies should be enhanced in strengthening the development of green finance. The most important thing for companies, regardless of the industry, is to interact with the government to improve their development goals and performance, maintain their rights and interests through political relations and policies, and obtain government support to achieve sustainable development of the company. Therefore, this study focuses on the political relationship between green finance development and financial performance and examines the intervention of political ties on corporate green investment and corporate performance. The results confirm that politically connected companies have more resources and protect the natural environment while improving their financial performance.
\end{abstract}

Keywords: Green finance development, Fiscal and tax policy, Sustainable development; Political connection, Business Performance.

\section{Introduction}

\subsection{Research Background and Research Purpose}

\subsubsection{Research Background}

The current financial system creates and trades financial assets to achieve sustainable development and provide greater access to financial services and people. Green finance is the foundation for shaping true prosperity through an environmentally friendly economic system and promoting sustainable financial instruments such as green bonds, green loans, and green mortgages (Flammer, 2020; Katona 2020). The two purposes of green finance are to be able to reduce the perception of risks in the current financial market, to achieve the purpose of low cost in the broader economy and environment, to combine the support of environmental protection policies, and to use the development of technology to make the economy environmentally-friendly (Khoshnava et al., 2019; Chen et al., 2021). Fossil fuel technology has been widely used in the past. Still, as times change and consumers seek fewer options, technological developments are causing the world to move away from fossil fuels rapidly, presenting some financial dilemmas and challenges and requiring tremendous effort (Bos \& Gupta, 2019). For example, investors in the United States obtained shareholder proposals to request information from banks targeting the financing aspects of fossil fuels (Griffin, Myers Jaffe, 2018). The financial sector also achieves sustainable transformation processes in line with consumer needs and the importance of environmental protection (Č́belková et al.,2020). Financial institutions, as financial services for their customers, should not only control their reality and pay attention to their impact in terms of investment and business, but also to the sectors that play a role to bring more benefits to the company (GarcíaSánchez et al. 2020). Liquidity providers can facilitate the transition to sustainable investment by providing liquidity to their products and making these products more accessible to end customers (investors who want to invest) (Louche et al., 2019). According to a recent European Commission report of the Office for the Coordination of Economic and Social Affairs (Optiver, 2020), companies such as Optiver Europe can reduce supply transmission, Especially if they can solve their problems by adopting green fiscal and financial policies and pushing volumes into liquid markets. Currently, institutional investors are more focused on hedging the impact of climate risk as new issuers enter the market and demand and supply for the green bond market in China (Deschryver, De Mariz, 2020).

Green finance is now the second largest investment vehicle in the U.S. market after equities (Faske, 2018). At present, China's investment in green financial bonds and other investment processes is more direct, and has set up a transparent system, is used to critically evaluate the sustainability of assets, to promote the sustainable growth of the economy, financial market and efforts to build a green, such as Green debt or green equity (Bolton et al., 2020). 
Unit: Trillion yuan \%

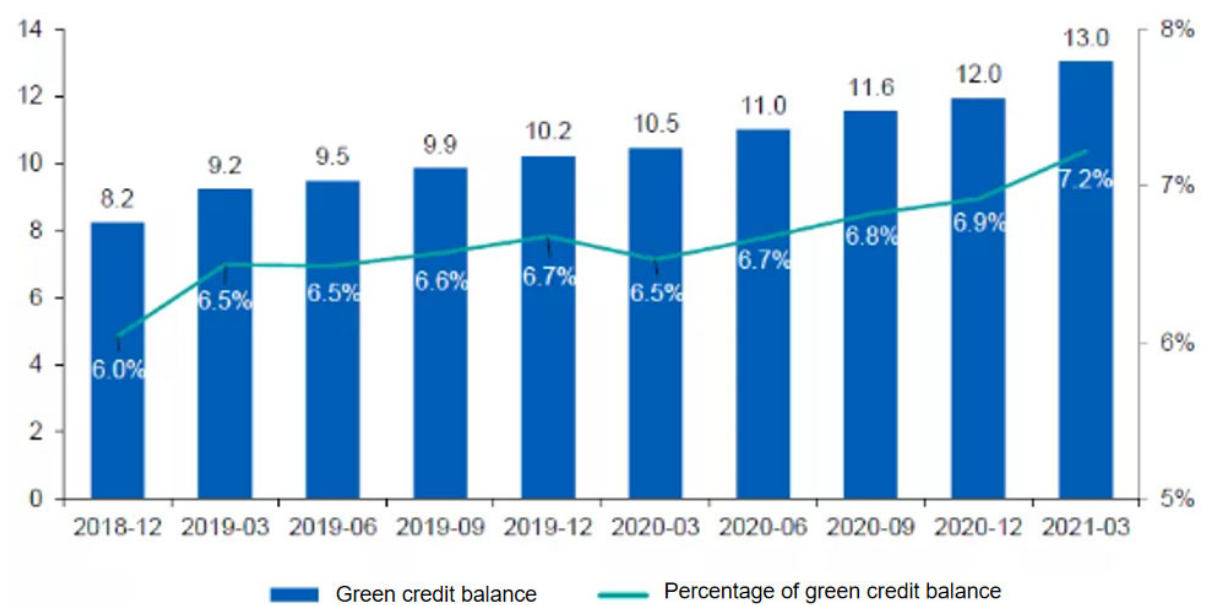

Figure 1. Green credit balance and percentage of major financial institutions in China Source: CBI, Wind

Unit: USD Billion

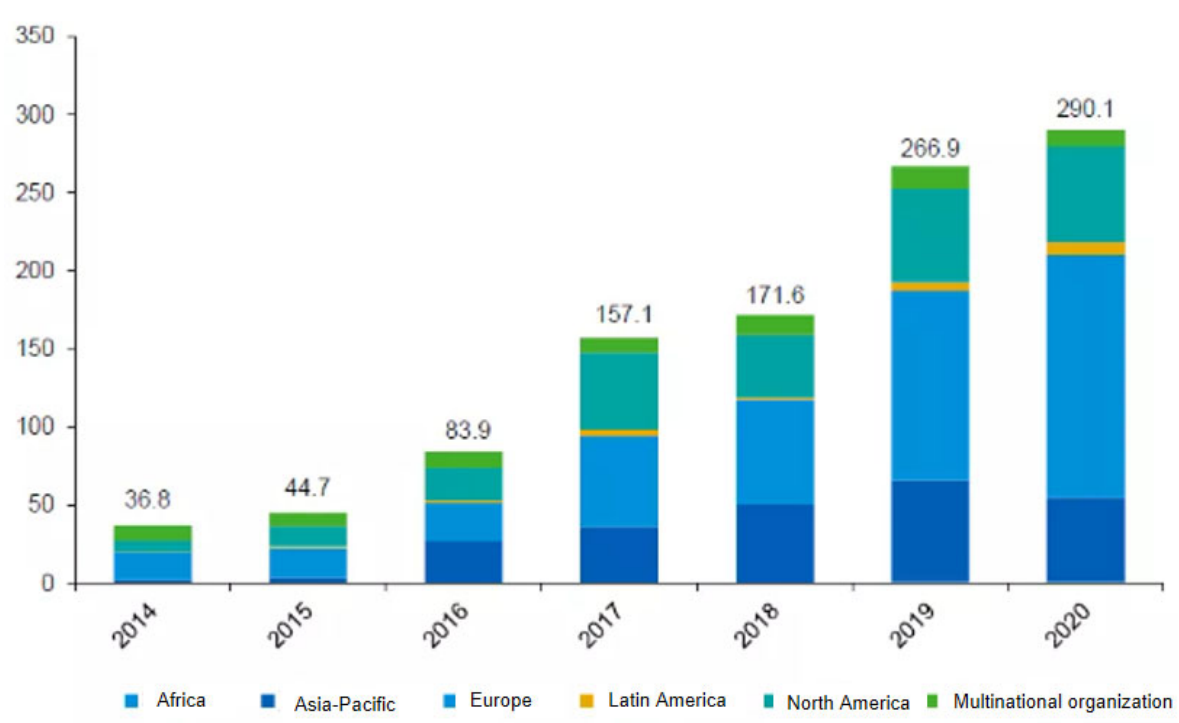

Figure 2. Global Green Bond Issuance by Major Regions, 2020

Source: CBI, Wind

Therefore, based on the above background and combined with the current content on fiscal performance in China, this paper analyzes to understand the political relationship between the two, and to provide a reference for related research by combining the characteristics of green finance.

\subsubsection{Research Significance}

Combined with the relevant studies reviewed, all further suggest a positive correlation between political connections and green finance. David \& Sinclair-Desgagné (2010) can obtain green investments through political links. Politically connected companies, supported by policies, can get financial incentives to access more funds and opportunities and expand their environmental performance towards sustainable development. According to resource dependency theory, Lin et al. (2015) argue that politically connected firms can achieve more significant green finance due to the accessibility of resources. Following the same premise, Wang et al. (2018) argued that political connections could obtain critical resources from the government and rationalize the allocation and adoption of green practices to shape good environmental performance.
Therefore, as highlighted in the above literature, companies with political connections have easier access to information and opportunities (Geden et al., 2018). In the development of green finance, political connections can help companies obtain more preferential treatment and government funding, significantly improving their earnings and financial performance and forming a more influential corporate reputation in the market. Therefore, this article combines the development of green finance to analyze the current financial performance of enterprises and further clarify whether there are political connections. It is hoped that improving company performance will bring important development channels, have a particular economic impact, and provide all experience and reference.

\subsection{Structure of This Article}

This paper takes the enterprises developing green finance as the research object and focuses on the relationship between enterprises' financial performance and political relations. When it is clear that enterprises with political backgrounds can gain more advantages in the development of green finance? Therefore, the structure of this paper is as follows: 
The first part summarizes the research background and significance of this paper. Further, it defines the overall framework of this study. Section 2 provides an overview of the definition and characteristics of green finance and addresses the correlation between political connections and green finance, followed by a further understanding of the performance of political relationships and corporate performance. Section 3 provides an overview of the research methodology of this study. The fourth section discusses the current situation in terms of fiscal policy in China today. It discusses the political relationship between green finance development and fiscal business and the analysis results to propose reform ideas to promote green finance budgetary policy. Finally, the conclusion section concludes the paper and provides some insights and perspectives of this study.

\section{Theory and Literature Review}

\subsection{Green Finance Overview}

The primary purpose of green finance is to establish a consensus on "greening" and clarify the role of finance as an essential part of the green economy. The management departments of relevant banks and enterprises must pay attention to the sustainable financial system shaped by green finance and jointly achieve sustainable development. Social goals (Migliorelli, 2021). Recently, many financial institutions and companies hope to achieve the net emission goal of zero carbon emissions by 2050 . Therefore, they analyze and formulate plans based on their internal and external environmental factors to avoid risk perceptions, encourage environmentally friendly investment, and achieve Green development (Shahbaz et al., 2020). It is feasible to implement a green financial effect on a large scale based on reducing energy consumption. Combining the existing greening infrastructure for construction, and the relevant economic policy proposed by the state, the company, implements plans and strategies based on this as an expected goal. It promotes an economically viable sustainable growth model of green finance. From 2016 to 2030, Asian developing countries will need to invest and mobilize new investments in renewable energy, energy efficiency, and energy-saving technologies (Nassiry, 2018; Strielkowski et al., 2019).

\subsection{Political Connections and Green Finance}

In contrast, many studies have shown that political connections and green finance are negatively correlated. For example, Morgan's (2013) seminal work suggests that the more connected a firm is to the government, the more it avoids emissions. Because government provides legal protection and reasonable resource allocation for its firms, they tend to take a negative attitude toward environmental responsibility, resulting in poor ecological signs. This also shows that possessing political connections makes these companies believe that they have a certain amount of power and thus do not fulfill their social responsibilities.

According to the relevant empirical analysis, the results show the positive correlation between the ownership of political relations and performance and the comparative analysis between the actual situation of the company and the trend of undertaking in environmental aspects. Nowadays, especially in developing countries, although the government promotes green finance, the management and measures in this area are not perfect but negatively impact the negative correlation between political connections and environmental performance. The government has introduced a series of steps to promote national development planning and green projects, introduce green technologies into more environmental policies, and fulfill their ecological responsibilities $(\mathrm{Li} \mathrm{W}$, Higgins P., 2013). Nowadays, the government is responsible for most relevant companies to promote the development of green finance and for the existence of political ties between companies and the government, which also need to assume the obligation to avoid responsibility and strengthen the regulation of this area.

\subsection{Political Connections and Firm Performance}

In the business world, political connections can positively affect a company's reputation and performance. Having a wide range of political connections can increase a company's daily sales and annual growth. Economic development can also contribute to the local economy, thus allowing companies and governments to develop and bring more progress. But there are two sides to everything, both positive and negative. In some countries, the threat of political extraction is more significant (Caprio L, Faccio M,2013). Therefore, some companies have political connections but do not support development. But instead, they topple to avoid responsibility and extract assets from political squeeze and sacrifice the legitimate rights of the people to gain additional benefits. In this case, having political connections, instead, can lose the reputation and value of the company and can even lead to financial risk problems and bankruptcy of the company.

\section{Paper Analysis}

\subsection{Current Fiscal and Taxation Policies}

As an essential part of environmental and economic policies, China has begun promoting green financial policies such as green credit, green insurance (ecological pollution liability insurance), and green securities during the "Eleventh Five-Year Plan" period. At present, these policies have made inevitable progress. Taking green credit as an example, since 2007, the Ministry of Environmental Protection, the People's Bank of China and the CBRC have promulgated the "Opinions on Implementing Environmental Protection Policies and Regulations to Prevent Credit Risks," "International Experience in Promoting Green Credit: Equator Principles and IFC Performance Standards and Guidelines," "Opinions on Further Improving Financial Services to Support Energy Conservation, Emission Reduction and Elimination of Backward Production Capacity," "Notice on Issuing Green Credit Guidelines," "Green Credit Statistical System," "Green Credit Statistical System," and "Green Credit Statistical System. Green Credit Statistical System", "Key Evaluation Indicators for Green Credit Implementation" and "Notice on Issuing Guidelines on Energy Efficiency Credit", guiding banking financial institutions to accelerate the promotion of green credit. Major domestic banking financial institutions have also been increasing their efforts to promote green credit, and the scale of green credit has been increasing. According to the CBRC, as of the end of June 2014, 21 major banking institutions had a balance of RMB 4.16 trillion in loans for energy-saving and environmental protection projects and services, accounting for $6.43 \%$ of their loans (He Xia: "Two Ministries Issue Energy Efficiency Credit Guidelines Focusing on Supporting Seven Major Areas," January 20, 2015, People's Daily Online.) 
(1) The rapid development of green funds

Venture capital funds and industrial investment funds in energy conservation and environmental protection are designed to provide means for the development of the green financial industry. From the government's point of view, some companies have political connections that enable the central and local governments to provide funds and support, incredibly strategic emerging industries, to obtain environmental protection industry investment funds established by social funds. These mainly offer policy bases and norms for local green funds with investment properties.

(2) Breakthrough in green bond policy

Both green financial bonds and green corporate bonds have received local guidance and encouragement. The government has provided political and technical support to facilitate its economic structure's adjustment, optimization, and development. On December 31, 2015, the National Development and Reform Commission also issued the "Green Bond Issuance Guidelines" (Fagaiban Caijin [2015] No. 3504). They supported functions such as solving major environmental problems, coping with climate change, and developing energy-saving and environmental protection industries.

Although there are many domestic types of research and discussions on green bonds, there has been no specific policy on green bonds for a long time. This situation was changed at the end of 2015. However, there were some limitations.

\subsection{Existing Problems}

Although domestic green finance has been developed to a certain extent, it is still in the development and exploration stage, and there are specific important problems. From a fundamental point of view, companies need to meet the green investment needs of collective energy and pollution control to form green financing needs, promoting green finance development. The goal of environmental protection in the museum is relatively high. Still, the environment is inadequate law enforcement, and some companies do not reasonably use the support and legal support, resulting in insufficient motivation for green investment and financing. The development of green finance also lacks real impetus.

The relevant literature on green finance bonds and green finance proposes that relevant government departments and local governments issue policy measures to provide support. However, some companies lack interest incentives, cannot obtain investment and financing channels, innovate investment and financing mechanisms in the environmental protection field.

\subsection{Discussion on the Political Relationship Between Green Finance Development and Fiscal and Taxation Performance}

Most studies have shown that political relationships positively impact company value, and politically connected companies account for a considerable proportion of the world stock market (Boubakri N et al., 2012). Second, close contact with the government can control market failures and avoid ideological discrimination, but privatized companies cannot handle all these tasks (Salamon LM, 1987). Many founders of the company have political backgrounds. They like to appoint the second generation as directors (Roberts PW. et al., 2011), which is economically essential and reduces transfer costs. By sorting out the literature reviewed and using different methods for analysis, the results prove that enterprises with political affiliation are easier to obtain long-term financing than those without political unions. There are political connections that must affect the performance of Indian companies. After rigorous research, it can be assumed that political relationships affect stock prices. It is precisely because of involvement in corruption that most political leaders cannot cooperate with companies (Yang D. et al., 2014).

Influential leaders are mainly measured by evaluating the efficiency of the company and its performance in the market. To be able to improve investment efficiency and obtain more benefits. Most companies hope to bring support through more channels, and in particular, the financial industry now needs to be over-developed towards green finance. To nurture enterprises, they must first improve cost efficiency, and political connections help companies cost-effectively. In fierce competition, politically connected companies can obtain the latest technical skills, employees, national resources, etc. These can help the company get better production, gain more market share, and survive in the big market. Improving the company's cost efficiency will further have political relationships based on relevant literature and news, enabling companies to obtain higher production levels. At the same time, the government will also provide companies with various advantages. Enhance the effective strategic development of enterprises. Therefore, all this evidence proves that political connections positively impact company performance.

A growing body of literature suggests that political associations provide a valuable resource for business incubation. Political connections are more prevalent in developed financial markets like the United States ( $\mathrm{Li} \mathrm{H}$ et al. 2008), and their shareholders are well protected. Especially in improving the development of green finance, compared with other companies, politically connected companies have a larger market share (Khwaja AI, Mian A., 2005), pay lower taxes, and obtain green technology. The more support it has, and the government will provide it with more financial and credit channels to increase the intensity of the development of green finance. In addition, politically connected financial companies impose election costs on their shareholders like those in developed countries. This political connection is caused by the separation of ownership between the principal and the agent. The principal-agent problem can cause organizational slack in a company, and managers make decisions for their benefit, such as hiring idle employees to do their work (Jensen MC, 1986). It is necessary to eliminate the contradiction between managers and employees to improve efficiency. The key is to have a better incentive mechanism. Politically connected companies have exacerbated agency problems due to their influence, damaging their efficiency. Therefore, the prerequisite for the development of green finance is that the company must have political connections. Still, the common internal control, strategy, and the company's financial and tax performance must be precise to bring better impetus to the development of green finance.

\section{Conclusions}

With the concept of environmental protection and sustainable development taking root in people's minds, green ideas are being developed globally for the social and ecological aspects of enterprises, and the improvement of various financial products and infrastructure included in the green financial market will help improve the quality and 
efficiency of green financial services. Companies with political affiliations can get more financial support with contributions. Previous studies have different results proving its positive impact on firm performance, including tax exemptions, state resources, power access, preferential use of leverage, and gaining significant market share (Fisman R, 2001).

In general, political connections will positively impact company performance and fiscal and taxation. There are also negative influences on excessive political relations, which will not only damage the company's environmental performance but also bring more costs and even face financial problems. So for better promotion of the company's green financial development, and rational use of political relations to generate resources is of great practical significance for cultivating companies.

\section{References}

[1] Ang JS, Ding DK, Thong TY. Political Connection and Firm Value. Asian Development Review, Vol. 30 (2), pp. 131-166.

[2] Boubakri N, Guedhami O, Mishra D, Saffar W. (2012). Political connections and the cost of equity capital. Journal of corporate finance; 18(3):541-59.

[3] Caprio L, Faccio M, McConnell JJ. (2013). Sheltering corporate assets from political extraction. The Journal of Law, Economics, \& Organization.29(2):332-54.

[4] Cho CH, Patten DM, Roberts RW. (2016). Corporate political strategy: An examination of the relation between political expenditures, environmental performance, and environmental disclosure. Journal of Business Ethics. 67(2):139-54.

[5] David M, Sinclair-Desgagné B. (2010). Pollution abatement subsidies and the eco-industry. Environmental and Resource Economics. 45(2):271-82.

[6] Fisman R. (2001). Estimating the value of political connections. American economic review.91(4):1095-102.

[7] Faske B. (2018). Turning billions into (green) trillions: Tracking the growth and development of the green bond market in China, France, India, and the United States. Tulane Environmental Law Journal 31(2): 293-325.

[8] Flammer C. (2020). Green bonds: effectiveness and implications for public policy. Environmental and Energy Policy and the Economy 1(1):95128.https://doi.org/10.1086/706794
[9] Li H, Meng L, Wang Q, Zhou LA.(2008). Political connections, financing and firm performance: Evidence from Chinese private firms. Journal of development economics. 87(2):28399.

[10] Liu Y., Lee J.M., Lee C. (2020). The challenges and opportunities of a global health crisis: the management and business implications of COVID-19 from an Asian perspective. Asian Business \& Management 19:277297.https://doi.org/10.1057/s41291-020-00119-x

[11] Louche C., Busch T., Crifo P., Marcus A. (2019). Financial markets and the transition to a low-carbon economy: Challenging the dominant logics. Organization \& Environment 32(1), 3-17. https:// doi.org/10.1177/1086026619831516

[12] Lu J., Ren L., Yao S., Qiao J., Strielkowski W., Streimikis J. (2019). Comparative review of corporate social responsibility of energy utilities and sustainable energy development trends in the Baltic states. Energies 12(18): 3417.https://doi.org/10.3390/en12183417

[13] Li W, Higgins P. (2013). Controlling local environmental performance: An analysis of three national environmental management programs in the context of regional disparities in China. Journal of Contemporary China. 22(81):409-27.

[14] Lin H, Zeng SX, Ma HY, Chen HQ. (2015). How political connections affect corporate environmental performance: The mediating role of green subsidies. Human and Ecological Risk Assessment: An International Journal. 21(8):2192-212.

[15] Jensen MC. (1986). Agency costs of free cash flow, corporate finance, and takeovers. The American economic review. 76(2):323-9.

[16] Khwaja AI, Mian A.(2005). Do lenders favor politically connected firms? Rent provision in an emerging financial market. The Quarterly Journal of Economics. 120(4):1371-411.

[17] Migliorelli M. (2021). What do we mean by sustainable finance? Assessing existing frameworks and policy risks. Sustainability 13(2): 975.https://doi.org/10.3390/su13020975

[18] Rahman A. (2020). Currency Democracy: The Theory of Organic Global Monetary. New York: Global Currency Initiative.

[19] Salamon LM.(1987). Of market failure, voluntary failure, and thirdparty government: Toward a theory of governmentnonprofit relations in the modern welfare state. Journal of voluntary action research. 16(1-2):29-49.

[20] Yang D, Lu Z, Luo D.(2014). Political connections, media monitoring and long-term loans. China Journal of Accounting Research. 7(3):165-77. 